\title{
The Dynamics of Change in eService Implementation: The Case of Australian Local Government
}

\author{
Dr Chowdhury Golam Hossan (Corresponding author) \\ PhD Graduate, La Trobe University, Australia \\ and
}

Assistant Professor, College of Business Administration

Abu Dhabi University, Abu Dhabi 59911, UAE

Tel: 971-553-404-244 E-mail: chowdhury.hossan@adu.ac.ae

Dr Nicola McNeil

Lecturer, School of Management

Faculty of Law and Management, La Trobe University | Bundoora

Melbourne 3086, Australia

Tel: 61-3-9479-1471 E-mail:n.mcneil@latrobe.edu.au

\author{
Professor David Brown \\ Visiting Professor, School of Management, La Trobe University \\ Melbourne 3086, Australia \\ E-mail: d.brown@latrobe.edu.au
}

\author{
Received: April 29, 2011 \\ Accepted: June 21, $2011 \quad$ Published: November 1, 2011 \\ doi:10.5539/ijbm.v6n11p47 \\ URL: http://dx.doi.org/10.5539/ijbm.v6n11p47
}

An earlier version of this paper has been presented in the 23rd Annual Australian and New Zealand Academy of Management Conference, Melbourne, 2-4 December, 2009.

\begin{abstract}
Human resources management is becoming an increasingly critical factor in implementing eService into the local government sector. The movement towards eServices is a viable, sustainable option for improving service delivery. Within the context of technologically-driven organisational change, using data from 23 face-to-face interviews in 5 diverse City Councils, this research presents key barriers in adopting eServices as perceived by strategic leaders and employees in Australian local government, and describes strategies to overcome these barriers, recognising the role of strategic leaders and employee commitment to the change process.

Keywords: eService, Australian local government, Change management, Employee commitment, Leadership, Technological change

\section{Introduction}

A stated objective of the Australian government is to transform government services from a simple online presence, to one which enables citizens to access services electronically at all hours (National Office for the Information Economy, 2004). eGovernment emphasises the role of public organisations in providing effective, efficient, and better quality services at a lower cost (Shareef et al., 2010). Often referred to as eServices, or eGovernement when directly associated with Government online services (Ancarani, 2005; Burn and Robins, 2003; de Ruyter et al, 2001; Goldkuhl, 2007), many local governments have recognised that over the counter services are costly and inconvenient (Ancarani, 2005; Boyer et al, 2002; Henderson et al, 2003; Multimedia Victoria, 1998; National Office for the Information Economy, 2001; Ruyter et al, 2001). Effective implementation of eServices requires strong commitment of both government and its employees (Hossan et al., 2009; Deng, 2008), and although there is some growth in the use of eServices, there is limited research focusing on the extent of eService adoption in local government (referred to as City Councils) in Australia and how eServices can be enhanced in such a context (Huang, Ambra and Bhalla, 2002).

Strong commitment to lead electronic media encompassing the integration of business and technical goals and the formation of an appropriate organisational mindset, culture and structure are prerequisites to achieve change management needed for sustained commitment to eServices (Symonds, 2000). Highlighting the importance of leadership in change management, a Harvard University Report remarked that "Leadership to help the organisation adapt to information age challenges requires commitment and work from all quarters not just
\end{abstract}


directives from on high. Leaders must be engaged, and must keep their staff engaged (Harvard University Report, 2001, 3).

Change management techniques are often a pre-requisite for implementing eServices (Clark, 2003). Walsh (2007) notes that government decision-makers are generally reluctant to use information and communication technology, due in part to a growing political conservatism and inadequate IT skills. Government leaders often favour more direct participatory modes of democracy, and use of technology is considered as an aid to facilitate greater direct participation (Davidson 1997; Walsh, 2007). While there is an increasing positive impression about internet in recent years, "off-line" channels remains a highly favourable media for communication (Chen, 2002). The present research argues that responsibilities for designing and implementing eServices rests with City Council employees and key strategic leaders (Note 1) (or change agents), given the apparent reluctance of Australian political leaders to adopt online modes of service delivery. Within the context of organisational change, this research presents key factors that facilitate eServices adoption in a sample Australian City Councils, as identified by strategic leaders and employees and articulates strategies to overcome some common barriers and the role of employee commitment to the change process using empirical data.

\section{The Context: Local Government and eService Expectations}

City Councils in Australia represent a layer of government at the local level; the activities of City Councils are regulated by both Federal and State government authorities. City Councils are governed by the elected Councillors under the leadership of a mayor and are administrated by a Chief Executive Officer (CEO) with the support of other Council employees. Australian City Councils are responsible for more than 100 different services ranging from providing physical infrastructure services; local economic development; health welfare and community services; general public services; and environmental management (Municipal Association of Victoria, n.d.). In Australia, it is the role of City Councils to ensure that policy developed by higher levels of government meets the needs of the community, and City Councils have increasing power to influence the direction of community environments, service and infrastructure (Shackleton, Fisher and Dawson, 2004).

Of interest to this study is the extent of provision of eServices in local government in Australia. According to the report by Australian Government Information Management Office [AGIMO] (2008), four in every five Australian citizens use the internet. The report reveals that usage of the internet is also increasing among older people and that seven in ten houses in the metropolitan area have broadband connection. The AGIMO report found that nearly two-thirds of respondents interviewed in their study used the internet to contact government in 2007-2008. More than eight out of ten people prefer to use new technology such as email, SMS, instant messaging, social networking sites and blogs; in contrast, only three out of ten people use telephone (AGIMO, 2008). However, there is a gap between the demand for online services and the supply of online services in Australian government. Citizens report frustrations in dealing with government using eServices and indicate the need for improvement in website usability and content (AGIMO, 2008). Thus, while the technology for adopting eService is now available, there are apparent barriers to improving the supply of eServices in local government. It is acknowledged that there are numerous complex issues to explain the reluctance to improve eServices supply; however, this study aims to explore issues related to local government strategic leaders and employee commitment to adopting eServices. As active involved dedicated members of local government, strategic leaders and employees may be in the best position to influence key decision makers to improve the supply of eServices to the community.

\section{Theoretical Framework}

Enhancing eService adoption in Australian local government is explored within a change management conceptual framework. The notion of planned organisational change and Adoptive Structuration Theory (AST) are combined to explore key variables that influence the organisational change driven by the introduction of new information technology, such as resistance to change and employee involvement in change.

Lewin (1951) identifies two sets of forces that affect the management of change in organisations - those forces driving the need for change, and those forces that resist the change efforts. Lewin (1947) poses a 'three-step' model of planned change management, which consists of a 'freezing', 'moving' and 'refreezing' stage. Lewin's model still continues to underpin many contemporary change methodologies in organisations (Burnes, 2004a). Lewin (1947) argues that to manage change processes, an organisation must 'unfreeze' their current state into neutral position, so that old behaviour can be unlearned and new behaviour can be successfully adopted. Then change should be implemented by utilising 'driving forces' for change, and minimizing any resistance to the change process, which mainly comprised of emotional and psychological barriers. Once the change occurs, the organisation will consolidate its new position [called the 'refreeze' stage]. The change process is represented diagrammatically in Appendix C. The impetus for organisational change arises from opportunities and problems existing in the internal or external environment. Typically, an influential member of the organisation acts as an initiator to respond to the change stimuli. These 'change agents' play a major role in determining intervention and implementation strategies. This model provides a basic background of the planned change management process in any organisation.

The inclusion of elements of Adoptive Structuration Theory [AST] provides a framework to study variation in organisation change caused by implementing advanced technologies (DeSanctis and Poole, 1994). AST describes the inter-relationship between information technology, social structure and human interaction within an 
organisation change context. Rather than focusing on discrete information systems, such as billing or financial analysis, AST focuses on an integrated information system which creates social structures across different functional departments. It considers the structure required to adopt advanced technologies, and more importantly, the structure that emerges due to people interacting with technology in their work (DeSanctis and Poole, 1994). The implementation of eServices is more than a technological phenomenon, as it impacts on the management of human, technological, and organisational resources and processes (Grant and Chau, 2005). AST has been used to generate a clearer understanding of eService implementation processes at City Councils that introduce structural changes with new sets of rules, procedures and resources to facilitate technologically-driven organisational change.

\section{Research Methodology}

City Councils in the Melbourne metropolitan area were selected based on the profile of their community, budget, financial and infrastructural capacity. Initially ten City Councils were invited to participate in the project from a total population of seventy nine City Councils in Victoria. This project focuses on eServices in the metropolitan areas, because significant disparities exist in terms of access facilities between the metropolitan and regional areas. Initially, four City Councils were selected and subsequently, one more City Council was added due to its substantial involvement in eService initiatives in Victoria. Particular attention was given to ensuring a diverse range of Councils, particularly with respect to eService development. For example, Councils were characterised as having advanced level of development in eService, or conversely, an embryonic level of development on the basis of availability of online services available on their respective websites. Some Councils had insufficient access to internet infrastructure, while others were relatively well-resourced. Councils were also characterised as having static or rapid population growth, serving high or low income areas, and a high or low levels of cultural diversity (for example, 56 percent of residents of one Council reported speaking a language other than English).

A total of 23 in-depth face-to-face interviews were conducted over a period of three months in 2008 . To ensure a comprehensive understanding of the issues around eServices development, interviewees (respondents) comprised Directors (or CEOs), managers, team leaders and employees (officers) of City Councils. These people were selected on the basis that they could be viewed as potential 'strategic leaders' in fostering the change process through a joint consultation between the researcher(s) and respective Council authorities. Moreover, these officials are directly involved with the delivery of services. Their role in the organisation significantly impact on the organisation's eService offering capabilities. The eServices, on the other hand, alter the way they deliver their services and mode of their operation.

The semi-structured interviews covered five major areas of interest. The first section of the interview protocol concerned identifying the main drivers for introducing eServices, or the forces initiating the change to this service delivery mode. These questions cover issues such as resource and cost saving, staff reduction, expanding customer demand, more efficient customer service, and the Council's strategic direction. The second group of questions relate to the extent of the Council's restructuring to support the adoption of eServices. This question examines issues such as CEO and Councillor support, changes in the organisational structure and staffing. The next section of the interview protocol considers the processes used to facilitate the introduction of eServices, such as revisions to task process, process of service selection for eServices, the level of integration with other service deliver modes, changes to the technical structures and the creation of internal or external working groups to support eServices adoption. Issues around the staffing strategies employed to build support for eServices are also explored. This involves discussing the staffing strategies used to support eServices, staffing barriers to implementing eServices, the degree of employee participation in the change process and the strategies used motivate employees. The final section of the protocol concerns the most effective strategies and processes in terms of transition to eService delivery such as the IT System, re-structuring organisational processes, preparing staff for change and the availability of resources.

All interviews were conducted in person at the interviewee's workplace. Interviews were, on average, forty minutes in duration. All interviews were recorded using digital media with the consent of the interviewees and were subsequently transcribed. Interviewees had the option to review their transcripts before being processed for the data analysis to promote accuracy and cross-validation. Each interviewee was given a brief overview of the project at the beginning of the interview. Interviewees were aged between twenty-five years to sixty years of age. Respondents' experience working with City Councils (including other Councils) ranges from seven to thirty one years (refer to Appendix A for further information relating to the interviewees).

To ensure anonymity of the respondents, all transcripts were anonymised. Each interviewee is referred to as Respondent and assigned a number from one to twenty three. The transcripts were analysed using thematic content analysis, to identify the key barriers to adopting eServices in local government identified by respondents. The qualitative software NVIVO was used to facilitate this analysis.

\section{Results}

This section reports the most common barriers identified by staff in adopting eServices in City Councils and how change management tactics (see Figure 1) may assist in overcoming those barriers. Table 2 in Appendix B shows the thematic distribution of responses, where seven main themes were identified: barriers to implementation; the role of the CEO in adopting eServices; the role of a champion or change agent; the change management processes itself; workloads and role ambiguity; employee participation; and employee motivation. Each theme is 
discussed in turn.

\subsection{Barriers to the implementation of eServices}

Implementation of eService requires change in the way people work in an organisation, however almost 75 percent of respondents believe that there are barriers for implementing eServices in City Councils. While there has been no evidence of direct opposition from staff, lack of interest in eService was identified as a common barrier by the respondents. For example, with respect to training and development in eServices a coordinator revealed that “.....no one was absolutely negative. But there is some passive resistance...... (they) don't turn up (to training programs)." [Respondent 2]. And yet, elsewhere, Respondent 2 stated that lack of sufficient opportunities for training and development was sometimes seen as a barrier to employee involvement in change. Another challenge was to convince others of the benefits of eServices, in light of past negative experiences with IT. Delay in implementing IT projects was identified as one of the main reasons for losing people's focus on the area [Respondent 15]. Also, employees lose interest quickly if the system fails to deliver immediately [Respondent 16]. A further barrier related to the apprehension felt from the potential loss of control of increased on-line practices. For example, Respondent 10 explains:

"People use to do their job in their own way and they think putting things online means a loss of control. They would not be able to relax as much as they do now. They also think that the integrated process like generating forms online and directly feeding [sending] it back, would be a confusing process and out of their control."

Uncertainty about changes to workloads was identified as a barrier to eService implementation [Respondent 10 , 19]. Respondents explained that they often work with both the old and the new system during the conversion to eServices, which involves extra workload [Respondent 15]. Finally, age was mentioned as a challenge in adopting eServices [Respondent 3, 4, 5, 6, 16, 18]. For example, Respondent 5 commented, “...people who are in their late fifties very rarely use computers ..... [they] found it extremely challenging to use the new system. They found this simply not something that they can cope with."

\subsection{The role of $C E O$}

Approximately 50 per cent of respondents commented the importance of Chief Executive Officer support in adopting eServices in their Council. Respondent 3 discussed how the CEO alone had the capacity to change employee attitudes towards eServices within the Council. This CEO visited the United Kingdom and experienced state-of-the-art eService applications. The vision and enthusiasm gained from the experience fostered the momentum to embrace eServices in that Council. This CEO acquired new staff and the necessary technological upgrades to enhance eServices. Respondent 4 stated, "it is the CEO ... who promoted the motion for eService [following the UK experience] and Councillors are standing behind him". All respondents from that Council considered the CEO's experience with new technology changed the momentum for eService development in their Council. CEO's would be the very important change agent for adopting eServices if they have a personal interest for technology. However, many of the respondents revealed that it is essential that the CEO receives sufficient commitment and support from the Mayor and Councillors, along with other Executive Directors for successful adoption of eService [Respondents 1, 2, 4, 5].

Respondents from other participating City Councils expressed that it is important that the CEO understands the relationship between technological advancement and efficiency gains in the business process. For example, Respondent 1 mentioned that 'the CEO does not adopt technology for the sake of technology, he wants to see the business case.'

\subsection{Value of change agent}

The City Councils included in this study have more than 1500 staff including 300-500 administrative staff and an average of 17-20 business units. Such large bureaucratic organisational structures often make it challenging to implement a cross-functional system, such as eServices. Interviewees gave a number of different opinions about who the key person should be in generating eService change. More than $73 \%$ of respondents expressed their concern about the role of key people in adopting eServices.

Respondents indicated that the change agent should be an expert in technology, business processes, or both. For example, Respondent 10 said "It would be a fantastic idea to have one dedicated person to drive the whole process like a business analyst within the organisation". Views as to who the "change agent' should be are: the web administrator [Respondent 11], the manager of the business unit (not the IT unit) [Respondent 7, 14, 12, 15, $16,18,19]$, managers of key business area who have substantial public contact, such as the local laws officer or customer service providers [Respondent 8].

Some respondents believed that the change agent was not necessarily one person. However, managing too many champions can be another potential challenge for the IT department [Respondent 19]. Most respondents assumed that a successful champion should have qualities such as vision, networking, foresight and ability to generate internal and external funding. Moreover, the champion will need active support from the CEO and relevant directors to achieve success in implementing eService [Respondent 15, 16, 17].

\subsection{Change Management}

Ten respondents expressed their concern about change management issues impeding the development of eServices. Most respondents stated that there is need for more effective change management processes to foster the effective implementation of eServices. Some respondents considered change management as more important 
issue than the technology. For example, Respondent 5 believed that if employees favoured the system it would be easier to work with the system. For instance, Respondent 8 suggests:

"I think in a change management process the first stage is to explain to people what changes are occurring, and the way it is going to effect them. You can put out some broad messages if it is going to effect the whole organisation letting people know that change is coming in the first place - explaining why the change is occurring."

Furthermore, respondents suggest that there is a need for new ways to communicate, a need to avoid information overload and more importantly, a need for reassurance among staff.

\subsection{Workloads and role ambiguity}

More than half of the respondents interviewed indicated that more preparation was necessary to make the role of eServices clear to employees. The most common perception about eService among employees is that it will result in extra work. As Respondent 10 commented "I think people are generally interested but they are worried that it [eService] is going to generate extra work for them". Respondent 6 explained that people often are invited to be involved on an ad-hoc basis to support eService, without being released from their on-going responsibilities. This is also a source of role conflict amongst employees.

Further, Respondent 6 presented a case where people are de-skilled due to the implementation of new information systems. A lack of sufficient training, clear policy framework, vision and goals for eServices can lead to role ambiguity [Respondent $6,12,17]$. In order to overcome role ambiguity and other workplace challenges, respondents recommended management should quantify the benefits of eService and then promote this to general staff. [Respondent 3,7,10,14]. Respondent 8 believes that showing the bigger picture of eService would help people to get motivated and understand how they can contribute. Respondent 12 believes that the theoretical framework and philosophy can be a great tool to make roles and responsibilities clearer. It is also important that the organisation places realistic expectations on staff, even if the impact is unknown - it is better to be honest and tell the staff about the uncertainty [Respondent 9].

\subsection{Employee Participation}

Successful eServices adoption largely depends on employee involvement. This section addresses issues around participation, such as the importance of participation, timing, who should participate and how to measure employee participation. More than 60 percent of respondents made multiple references to different aspects of employee participation in City Councils during the interviews. The majority of the respondents state that participation is a great tool to reduce resistance for any change management in the Council. For instance, Respondent 21 believes that participation from all organisation levels may save unnecessary expenditure, as they know the real demand and usage of any new alternative channels. Respondent 9 also reports that the consultation process creates a sense of ownership towards the change, contributing to positive feelings amongst employees. Councils often use surveys, face-to-face meetings and online training to promote participation. However, Respondent 5 argues that online training is not the most effective tool and that email a poor tool for this type of communication.

Respondents stressed the need for finding new ways of communication. Team meetings were considered as an effective method, as employees are motivated because it is a sign that management is listening [Respondent 6]. Training programs, if well-targeted and well run, were also considered as an effective means of participation by the respondents. Respondents believe that participation could be encouraged in different ways, such as written letters of invitation, meetings, and group consultation [Respondent 9]. Some respondents reported that their business unit had a practice of encouraging staff to generate ideas and express opinions. A manger of a unit commented

"The purpose of communication is not only to make employees aware of the project but also to engage staff and take input from staff on how the business process might be improved by technology. " [respondent5]

All the respondents agreed that participation should begin at the time of idea generation, and not in the middle of the process or after the implementation. Early stage participation provides the advantage of more ideas, increased staff buy-in and smoother implementation according to respondents [Respondent 3, 14, 20].

\subsection{Employee Motivation}

Respondents reported that projects often face some sort of resistance or lack motivation from the general staff. It is not very unusual to have experienced people with a long working history struggling more with technology upgrades compared to younger professionals [Respondent 4]. Some respondents state that training often motivated people to adopt new technology. Respondent 10 considered feedback from key managers had a motivating effect on employees. Respondents also highlighted how eServices can benefit employees in their day to day operation and for their future career profile [Respondent 12, 6, 19].

"Motivating people is not such a problem. If you go there and talk to them then they get motivated. If you listen to them and sometimes they might feed you back with their frustration with the old system. If you go out there and show that you want to listen to them then they will talk. You need to talk to them informally." [Respondent 12]

Recognition was another motivator identified by staff. While rewards are a very popular way of recognising effort, just a simple acknowledgement in public is also very successful in motivating employees [Respondent 5, 9]. 


\section{Concluding Remarks}

This paper highlights some of the barriers to the effective implementation of technologically-driven change, such as the implementation of eServices in a sample of local government organisations in Australia. The conceptual framework adopted provides insight into some of the more important issues surrounding technological change in City Councils, and this was validated by the interview data collected from employees of City Councils in a number of instances. The findings support the critical role of strategic leaders (who could be the CEO or influential employees throughout the organisation) in designing and implementing technological change in the Councils. The results confirm well-established barriers to change, but examine these factors in the context of eService implementation and delivery. Factors such as a lack of interest in eServices, role confusion, passive resistance, fear of losing control with the adoption of online services and increased workload are in evidence. The management of the technological change process was a key aspect discussed by all the respondents. It is apparent that Councils often lack a clear vision and strategy for eServices, and consequently, employees can experience role ambiguity, increased workloads and disenchantment. Therefore, the effective management of the change process is of critical importance to any eServices initiative. To address some of these barriers to implementation, there is scope for greater employee participation in enhancing eServices at the early planning stage. The results indicate that City Council employees are ready to accept additional workloads if there is an appropriate explanation and support. Effective communication, feedback, recognition of effort and highlighting the potential of eService are considered effective tools for motivating employees.

There are a number of aspects of this research that limit its scope. The first limitation is the number of Councils represented in this study. Only five City Councils from Australia were selected for this study, and a greater number of Councils will provide more generalisable results. Another limitation is that all Councils included in this study are from metropolitan areas, which limits the generalisability of the results to rural or regional contexts. There is significant difference in the degree of eService development amongst urban and rural Councils in Australia (Teicher et al., 2002). Future research should sample a more representative mix of Councils, including Councils which govern rural and metropolitan areas.

This study represent a starting point for further research in this field, and obvious extensions include exploring the relationships between variables and linking this to outcome variables such as productivity, job stress and satisfaction of employees. In conclusion, this investigation provides some important clues for the development of an eService strategy in City Councils in Australia, and perhaps abroad.

\section{References}

Amith, K., and Berg, D. (1987). Paradoxes of Group Life. Jossey-Bass: San Francisco.

Ancarani, A. (2005). Towards quality e-service in the public sector: The evolution of web sites in the local public service sector. Managing Service Quality, 15(1): 6-23. http://dx.doi.org/10.1108/09604520510575236

Australian Government Information Management Office (AGIMO). (2008). Interacting with Government: Australians' use and satisfaction with e-Government services, Department of Finance and Deregulation, December. [Online] Available: http://www.finance.gov.au/publications/interacting-with-government/index.html (May 15, 2009)

Boyer, K., Hallowell, R., and Roth, V. (2002). E-service: operating strategy - a case study and a method for analysing operational benefits. Journal of Operating Management, 20: $175-88$. http://dx.doi.org/10.1016/S0272-6963(01)00093-6

Burn, J, and Robins, G. (2003). Moving towards e-government: a case study of organisational change processes. Logistic Information Management, 16(1):25-35. http://dx.doi.org/10.1108/09576050310453714

Burnes, B. (2004a). Kurt Lewin and the Planned Approach to Change: A Re-appraisal. Journal of Management Studies, 41(6): 977-1002. http://dx.doi.org/10.1111/j.1467-6486.2004.00463.x

Chen, P. (2002). Virtual representation: Australian elected representatives and the impact of the Internet. Journal of Information, Law and Technology. [Online] Available: http://www2.warwick.ac.uk/fac/soc/law/elj/jilt/2002_3/chen/ (3. July 17, 2009)

Clark, E. (2003). Managing the transformation to E-Government: An Australian Perspective. Thunderbird International Business Review, 45(4): 377-397. http://dx.doi.org/10.1002/tie.10087

Davidson, A. (1997). From subject to citizen: Australian citizenship in the twentieth century. Cambridge, UK: Cambridge University Press. http://dx.doi.org/10.1017/CBO9780511518232

De Ruyter, K, Wetzels, M and Kleijnen, M. (2001). Customer adoption of e-Service an experimental study. International Journal of Public Sector Management, 12(2): 184-207.

Deng, H. (2008). Towards objective benchmarking of electronic government: an inter-country analysis. Transforming Government: People, Process and Policy, 2(3): 162-176.

DeSanctis, G., and Poole, M.S. (1994). Capturing the Complexity in Advance technology Use: Adaptive Structuration theory. Organisation Science, 5(2): 121-147. http://dx.doi.org/10.1287/orsc.5.2.121

Feidler, F.E. (1964). A Contingency Model of Leadership Effectiveness. Advances in Experimental Social Psychology, 1: 149-190. New York: Academic Press. http://dx.doi.org/10.1016/S0065-2601(08)60051-9

Goldkuhl, G. (2007). What does it mean to serve the citizen in e-services? Towards a practical theory founded in 
socio-instrumental pragmatism. International Journal of Public Information Systems, 3: 135-159.

Grant, G., and Chau, D. (2005). Developing a Generic Framework for E-Government. Journal of Global Information Management, 13(1): 1-30. http://dx.doi.org/10.4018/jgim.2005010101

Harvard University. (2001). John F. Kennedy School of Government at Strategic Computing and telecommunications in the public sector: eight Imperatives for leaders in a networked world. [Online] Available: www-01.ibm.com/industries/government/ieg/pdf/Imp1.pdf (June 23, 2009)

Henderson, J., McGoldrick, E., and McAdam, R. (2003). A critical review of e-service in Northern Ireland Electricity. Managing Service Quality, 13(6), 463-470. http://dx.doi.org/10.1108/09604520310506522

Hossan, C. G., Joiner, T., and Brown, D. (2009). 'Enhancing eServices in Australian Local Government: The Role of Strategic Leaders and Employee Commitment to Change', published in the proceedings of the 23rd Annual Australian and New Zealand Academy of Management Conference, ANZAM 2009, Melbourne, Australia.

Lewin, K. (1947). 'Frontiers in group dynamics.' in Cartwright, D. (Ed.) Field Theory in Social Science. London: Harper and Row.

Lewin, K., (1951). Field Theory in Social Science. Harper and Row: New York.

McKelvey, W., and Aldrich, H. (1983). Populations, natural selection and applied organisational science. Administrative Science Quarterly, 28(1): 101-28. http://dx.doi.org/10.2307/2392389

Multimedia Victoria. (1998). 'Online Government 2001- from Vision to Reality.' Department of State Department, State Government of Victoria, Melbourne.

Municipal Association of Victoria. (no date). 'Councils Responsibilities Fact Sheet.' The Municipal Association of Victoria, (January 10, 2009) Anline] Available: http://www.mav.asn.au/CA256C2B000B597A/page/Council+Information-About+Local+Government?OpenDoc umentand $1=20$-Council + Information $\sim$ and $2=05$-About + Local + Government $\sim$ and $3=\sim$

National Office for the Information Economy. (2001). Government online survey results. National Office for the Information Economy, Canberra.

National Office for the Information Economy. (2004). Integrated services. National Office for the Information Economy, Canberra.

Robbins, S.P., and Barnwell, N. (1998). Organisation Theory: Concepts and Cases, 3rd ed., Australia: Prentice Hall.

Shackleton, P., J. Fisher and L. Dawson. (2004). Internal and External Factors Impacting on E-Government Maturity: A Local Government Case Study. Journal of Information Technology Cases and Applications; 6(4): 36-50.

Shackleton, P., J. Fisher and L. Dawson. (2006). E-government services in the local government context: an Australian case study. Business Process Management Journal, 12(1): 88-100. http://dx.doi.org/10.1108/14637150610643788

Shareef, M.A., Kumar, V., Kumar, U., Chowdhury, A.H., and Misra, S. C. (2010). E-Government Implementation Perspective: Setting Objective and Strategy. International Journal of Electronic Government Research, 6 (1): 59-77. http://dx.doi.org/10.4018/jegr.2010102005

Symonds, M. (2000). Survey: Government and the Internet: The Next revolution: After e-commerce get ready for e-government. The Economist, $24^{\text {th }}$ June: 355.

Teicher, J., Hughes, O., and Dow, N. (2002). E-government: A new route to public sector quality. Managing Service Quality, 12(6): 384-393. http://dx.doi.org/10.1108/09604520210451867

Walsh, L. (2007). A Case Study of Public Servants Engaged in E-Consultation in Australia. International Journal of Electronic Government Research, 3(4): 20-37. http://dx.doi.org/10.4018/jegr.2007100102

Wayne Huang, W., D.J. Ambra and V. Bhalla (2002). An Empirical Investigation of the Adoption of E-Government in Australian Citizens: Some Un-expected Research Findings. Journal of Computer Information Systems, 43(1): 15-22.

Weill, Peter \& Olson, M.H. (1987). 'An Assessment of the Contingency Theory of MIS.' Information Systems Working Papers, Stern School of Business, New York University, IS- 87-31. Retrieved March 28, 2008 from http://hdl.handle.net/2451/14487

Weill, Peter \& Olson, M.H. (1989). An Assessment of the Contingency Theory of Management Information Systems. Journal of Management Information Systems, 6(1): 59-85.

\section{Note}

Note 1 . The term strategic leaders refers to managers heading a business division, department or units at City Councils who are responsible for planning and implementing operational changes at their respective fields. 


\section{Appendix A}

Table 1. Respondents Backgrounds

\begin{tabular}{|l|l|}
\hline \multicolumn{1}{|c|}{ Code Name } & \\
\hline Respondent1 & IT manager \\
\hline Respondent2 & eServices coordinator \\
\hline Respondent3 & Communication and research manager \\
\hline Respondent4 & Human resource manager \\
\hline Respondent5 & Internal audit manager \\
\hline Respondent6 & Unit manager, citizen services \\
\hline Respondent7 & Governance and community relation manager \\
\hline Respondent8 & IT manager \\
\hline Respondent9 & Organisation development manager \\
\hline Respondent10 & Website and community information officer \\
\hline Respondent11 & Customer service coordinator \\
\hline Respondent12 & Organisational development research officer \\
\hline Respondent13 & Customer service manager \\
\hline Respondent14 & Human resource manager \\
\hline Respondent15 & Business Analyst team leader \\
\hline Respondent16 & eService coordinator \\
\hline Respondent17 & Infrastructure and technology director \\
\hline Respondent18 & Technology solution and development team leader \\
\hline Respondent19 & IT infrastructure coordinator \\
\hline Respondent20 & Finance manager \\
\hline Respondent21 & Customer service coordinator \\
\hline Respondent22 & IT manager \\
\hline Respondent23 & Communication coordinator \\
\hline
\end{tabular}




\section{$\underline{\text { Appendix B }}$}

Table 2. Thematic Distribution of respondents

\begin{tabular}{|c|c|c|}
\hline THEME & $\begin{array}{c}\% \text { of } \\
\text { respondents }\end{array}$ & EXAMPLE \\
\hline $\begin{array}{l}\text { Staffing challenges } \\
\text { to implement }\end{array}$ & $74 \%$ & $\begin{array}{l}\text { "People used to do their job in their own way and they think putting } \\
\text { things online means a loss of control. They would not be able to } \\
\text { relax as much as they do now. They also think that the integrated } \\
\text { process like generating forms online and directly feeding [sending] it } \\
\text { back would be a confusing process and out of their control." } \\
\text { [ Respondent 10] }\end{array}$ \\
\hline $\begin{array}{l}\text { CEO played very } \\
\text { important role for } \\
\text { adopting eServices }\end{array}$ & $45 \%$ & $\begin{array}{l}\text { "It is the CEO ... who promoted the motion for eService [following } \\
\text { the UK experience] and Councillors are standing behind him". } \\
\text { [Respondent } 4 \text { ] }\end{array}$ \\
\hline $\begin{array}{l}\text { Need key people as } \\
\text { champion }\end{array}$ & $75 \%$ & $\begin{array}{l}\text { "They hired the organizational development manager who was the } \\
\text { main person behind this strategy and eServices. He worked for the } \\
\text { director and it goes to the CEO through the director. He was the } \\
\text { main instigator and behind the multimedia strategy. And he was } \\
\text { strongly supported by the CEO and the Director". [Respondent 16] }\end{array}$ \\
\hline $\begin{array}{l}\text { Change } \\
\text { management }\end{array}$ & $44 \%$ & $\begin{array}{l}\text { "..... change management is more important than technology. } \\
\text { Getting the people on side is more important then getting the system } \\
\text { working". [Respondent 5] }\end{array}$ \\
\hline $\begin{array}{l}\text { Workload and role } \\
\text { ambiguity }\end{array}$ & $57 \%$ & $\begin{array}{l}\text { "I think people are generally interested but they are worried that it } \\
\text { will generate extra work..... People can't see the benefits of the new } \\
\text { system. Management can see but people at the ground level don't } \\
\text { know what is in it for them in the new system". [Respondent 10] } \\
\text { "If people see it is good for the organisation people would be happy } \\
\text { use them even if it means some extra work". [Respondent 20] }\end{array}$ \\
\hline $\begin{array}{l}\text { Employee } \\
\text { participation }\end{array}$ & $61 \%$ & $\begin{array}{l}\text { "As long we can get them involved early in the process and } \\
\text { document stages, it normally goes very smoothly. You need to get } \\
\text { staff early enough to get better acceptance. They also like to think } \\
\text { that they are in control of the process...even sometimes if they have } \\
\text { to do extra work but they would like to be in control of the process". } \\
\text { [Respondent 20] }\end{array}$ \\
\hline $\begin{array}{l}\text { Motivating } \\
\text { employees }\end{array}$ & $52 \%$ & $\begin{array}{l}\text { "You need to make them understand that it is going to be a benefit } \\
\text { for their job or career. You might say this is a project you want him } \\
\text { to be involved in. This might not help him to do day to day work but } \\
\text { it will look good in his CV. So unless you get buy-in it is difficult to } \\
\text { get people on board.... There is lot of passive resistance. People } \\
\text { get interested when people find some meaning for them". } \\
\text { [Respondent 19] }\end{array}$ \\
\hline
\end{tabular}




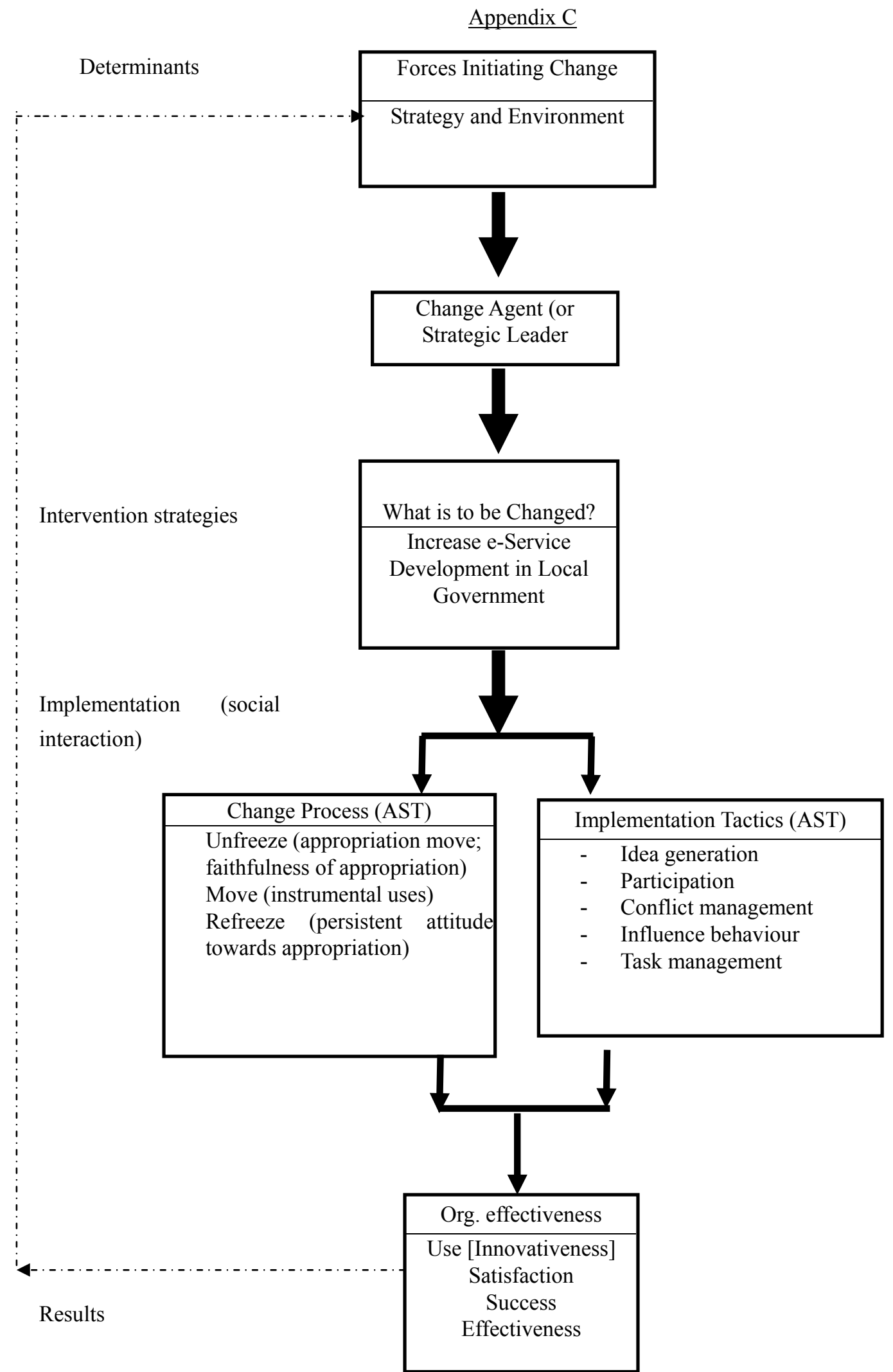

Figure 1. Research Model for eService Change Management in Local Government

(Based on Robbins and Barnwell (1998) and De Sanctis and Poole, 1994) 